UDC 373.211.24

DOI: 10.52534/msu-pp.7(3).2021.62-70

\author{
Abram Burnell ${ }^{1}$, Vera Pozsgay ${ }^{2}$, Iryna S. Kravets ${ }^{3 *}$ \\ ${ }^{1}$ Hanoi University of Science and Technology \\ 1 Dai Co Viet Road, Hanoi, Vietnam \\ ${ }^{2}$ University of Kragujevac \\ 34000, бб Јована Цвијића, Kragujevac, Serbia \\ ${ }^{3}$ Taras Shevchenko National University of Kyiv \\ 01033, 64 Volodymyrska Str., Kyiv, Ukraine
}

\title{
Corporate Culture in Preschool Organisation Administration: European and Asian Context
}

\section{Article's History: \\ Received: 20.06.2021 \\ Revised: 10.07.2021 \\ Accepted: 31.08 .2021}

\section{Suggested Citation:}

Burnell, A., Pozsgay, V., \& Kravets, I.S. (2021). Corporate culture in preschool organisation administration: European and Asian context. Scientific Bulletin of Mukachevo State University. Series "Pedagogy and Psychology", 7(3), 62-70.

\begin{abstract}
The relevance of the study lies in the need to introduce corporate culture in the field of preschool education to improve the managerial level and pedagogical compliance of employees who influence the development of preschool children as individual members of society. The purpose of the study is to analyse organisational culture in the administration of preschool institutions, based on a comparison of Asian and European cultural paradigms. The research consisted of two stages, namely theoretical and empirical, and involved the use of general scientific research methods, including analysis, synthesis, comparison, systematisation, questionnaires, surveys, and statistical data processing. In the course of the study, foreign scientific literature was analysed in order to determine the phenomena of preschool institution administration and its corporate culture. An empirical study was conducted, the essence of which was an online survey among kindergarten administrators in Germany and Kazakhstan. It is determined that both the German and Kazakh corporate administration cultures have weaknesses, common to which is the lack of full-fledged freedom in decision-making and conducting activities. It was discovered that the two countries have a common view on the development of administrator's corporate competencies, including strategic importance, change management, leadership, performance management, learning orientation, responsibility, focus on results, activity, and social intelligence. It is confirmed that German kindergarten heads are distinguished by their productivity and focus on learning, while Kazakh ones attempt to pay attention to responsibility and thoroughness. The practical value of the research is to compare two views on the corporate administration culture in preschool organisations in the context of European and Asian paradigms
\end{abstract}

Keywords: preschool educational institution, organisational culture, teacher training, administration in education, questionnaires

\section{INTRODUCTION}

Modern professional conditions impose new requirements for the functioning of any organisation, in particular, educational. Those requirements promote the idea that administration and education go beyond the two-dimensional vertical model, as a result, the teachers cease to be just "carriers of knowledge" or "subordinates", they are perceived as part of the team and the organisation. Such a horizontal model of interaction is created in the conditions of certain values, views inherent in a particular team, which generally establishes "corporate" or "organisational" culture. The existence of such a culture in educational institutions is essential since it contributes to the development of a positive psychological and value environment both in the team and in a teacher-student relationship. It is especially worth noting 
the importance of organisational culture in preschool education, which is associated with the age of its participants and their personality establishment in modern society. From this standpoint, it is also important to factor in the impact of the Internet and social networks on the corporate culture of an educational institution, which are used to communicate with pupils/students $[1 ; 2]$.

Such a change in socio-cultural views and the accelerated development of corporate culture within the field of education have necessitated research on the given subject. Thus, E. Addai in the study compared the corporate culture and involvement of teachers in professional activities [3] The results of the survey conducted by the author confirmed the existence of four types of organisational culture, namely involvement, adaptability, continuity, and mission. Moreover, it was established that the improvement of these types of corporate culture contributes to the growth of teachers' interest in their work [3]. Regarding the issue of organisational culture in preschool institutions, it is appropriate to pay attention to the conditions of its development identified by D. Bersteneva [4]. The researcher asserts the need for an information environment, a positive reputation of the organisation and its administration, a promising view on the personal growth of each employee, proper working conditions, both material and psychological, as well as general customs of the educational organisation [4]. L. Naumova, when studying the functioning of kindergartens, considered the elements of their corporate culture, including the mission, logo, service etiquette, organisational style and events, dress code [5]. Notably, this list of components is not exhaustive, since each educational organisation has the right to highlight or add its own elements of corporate culture in accordance with its customs and priorities. The results of the experiment by J. Park and J. Lee are of particular interest within this study [6]. The researchers conducted a survey of teachers, which showed the relationship between corporate culture and burnout, as well as the desire of teachers to change jobs. Moreover, a special influence of a clan or "family" culture on the burnout of educators was disclosed [6]. H. Kim and H. Hwang studied corporate culture in a holistic system, which included organisational culture, the development of leadership skills of the administrator, the establishment of the creative skills of teachers, and the educational process as a whole [7]. Upon using a survey, Korean researchers confirmed the correlation between these components of the system, the positive impact of their improvement on the educational process of kindergarten and the development of each child [7].

The analysis of scientific literature allows drawing a conclusion about the relevance of studying corporate culture in preschool educational organisations solely in the general context of certain geographical and cultural boundaries. Therefore, the research purpose is an analysis of the corporate culture in the administration of preschool institutions based on the comparison of Asian and European cultural paradigms. To achieve this purpose, the following tasks were completed: analysis of the specific features inherent to the administration model of preschool educational organisation and the development of corporate culture within kindergartens; identification of the corporate culture features in the administration of preschool educational organisations in the Asian and European educational space upon comparing the practices of kindergartens in Germany and Kazakhstan.

\section{MATERIALS AND METHODS}

The study of corporate culture in the administration of a preschool educational organisation was conducted in two stages. The first stage provided for the analysis of theoretical scientific literature to identify the features of "preschool organisation administration" and "corporate culture of a preschool organisation" and their functioning in practice. The second stage is designed to conduct an empirical study, the essence of which was an online survey among administrators of German and Kazakh preschool educational institutions to compare their functionality in the field of the corporate culture.

During the first stage, methods of analysis, synthesis, systematisation, and comparison were used. The analysis was used to process foreign scientific and methodological literature to describe the administration model of a preschool educational institution and to determine the organisational culture of a kindergarten. The synthesis was applied for a holistic study of corporate culture in the administration of a preschool organisation, based on combining its components, that is, the administration system and organisational culture. The systematisation allowed representing tasks for improving the level of corporate culture, the system of corporate communication in kindergarten, methods of supporting and stimulating teachers of preschool educational institutions, developing corporate culture, in particular its characteristics and sources. The comparison method collated the practices of introducing corporate culture in the administration of German and Kazakh preschool organisations.

During the second stage of the study, that is, empirical, questionnaires, surveys, and data processing were used. At this stage, electronic invitations to participate in the study of corporate culture in the administration of a preschool organisation among 200 kindergartens in Germany and Kazakhstan were sent, which were accepted by representatives of 50 preschool educational institutions with an equal number from each country. The total number of respondents was 150 people. After compiling the sample, an online questionnaire was generated using the Google Forms service in Russian and German. The questionnaire contained 30 questions, including 22 closed-type questions and 8 open-type questions. The survey was focused on identifying the weaknesses of corporate culture in the administration of preschool institutions in these countries, key corporate competencies, their level, including strategy, change management, leadership, service management, the level of interest in training and improving qualifications, ability to mentoring, responsibility, diligence, focus on results, 
effective communication, and command service, energy, initiative, and social intelligence. After being compiled, the application form was sent to the provided email addresses of representatives of kindergartens in Germany and Kazakhstan. The survey data was received by e-mail, and the responses of the administration of German and Kazakh preschool educational institutions were processed. Statistics of the study results for the purpose of cross-cultural exchange were sent to all survey participants.

\section{RESULTS AND DISCUSSION}

\section{The theoretical basis of corporate culture and admin- istration of preschool organisations}

The study of corporate culture in the administration of a preschool organisation requires consideration of the specific features inherent to each of its elements, in accordance with which the possibility of comparing practices in different cultural contexts will be presented in the future. To begin with, the administration model has its own characteristics in the paradigm of preschool education. The main requirements for the administration model of a preschool educational institution are adaptability to rapidly changing socio-economic and pedagogical conditions, its openness, which allows administration subjects to integrate new structures and content into the system timely; excluding the imitations in the administration of preschool educational institutions, encouraging creativity, eliminating strict regulations. The staff of an educational institution should be focused on constant transformations to ensure its development [8]. The organisation of the pedagogical process is considered a complex system consisting of certain interrelated elements. Such elements are the goals, tasks, means, forms, methods, the subject and object of administration, the principles and functions that determine its activities. Notably, the goals that determine the activities of administration subjects should comply with the purposes and tasks of the pedagogical process: the development of the children's personalities, meeting their need to discover the world and themselves, therefore, all members of the team

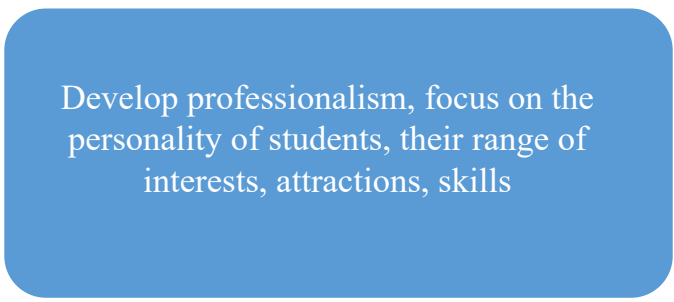

Introduce children to the values and provisions of corporate culture, adapt them to incidents in kindergarten, its customs, to the relationship features; prevent possible unfavorable moments in the group of students caused by interpersonal misunderstanding

in a preschool educational institution should recognise the uniqueness of the child's personality. The personality development of a preschool child is most successfully fulfiled when the administrative actions at a preschool educational institution are combined with the desire of teachers to provide the child with pedagogical support in its development and establishment, improve teaching methods, and implement their own administration concept for educational institution. The implementation of such a concept largely depends on the set of administration principles [9]. The administration principles are the main provisions that guide the administration subject in its activities, implementing it in certain socio-economic conditions: goal setting, complexity, democratisation, psychologisation of educational models. In this context, it is worth considering the corporate culture in a preschool organisation since the subject of administration is both its creator and carrier. The corporate culture features of the preschool institutions allow identifying the distinctive essence of the provided educational organisation, its current differences from others; discovering the limitations of administrative actions within the provided organisational culture; anticipating the response of the pedagogical team to certain innovations and the level of counteraction to changes; determining the actual cause of almost all conflicts; acquiring aspects of the applicability of the experiment of other organisations to the provided team $[10]$.

The corporate culture in a preschool educational institution can be developed in two areas: external and internal. External administration is the use of a complex of measures to withstand the growing competition of kindergartens, that is, company actualisation. Internal area introduction of corporate pedagogical values, standards of pedagogical relationships, an impactful educational culture that provides a suitable moral and mental environment, a creative atmosphere among the employees of a preschool educational organisation that promotes professional pride, provides positive conditions in the kindergarten and the team [11]. To achieve a high level of corporate culture, several tasks need to be set and completed, such as (Fig. 1):

Find the latest approaches to the joint activities of professional society members

to improve the competitiveness of the kindergarten, strengthen the spirit of integrity, union, harmonise individual interests and the interests of the team

Strengthen the spirit of the kindergarten team (creating and holding children's and family holidays; cultivating attributes and symbols; encourage communication between students of different age groups, increasing interaction between teachers and students)

Figure 1. Tasks for improving the level of the corporate culture 
The areas indicated in Figure 1 are implemented through the following events: training of democratic behaviour, social entertainment, conflict management training. These events also include the database of mottos, scenarios of corporate holidays of preschool educational institutions,

- Creation of a pedagogical club in kindergarten

-Intra-corporate publications

- Organisation of professional competitions as a means of developing a competitive environment

- Designing a kindergarten website to highlight its events, traditions, achievements

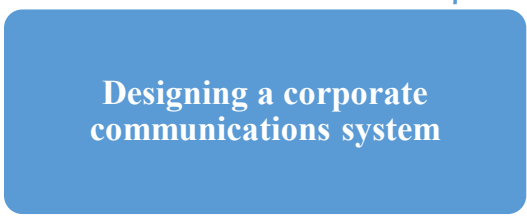

paraphernalia, symbols, and logos. Therewith, a system of corporate communications is necessary for the full development and maintenance of corporate culture, as well as for holding such events (Fig. 2).

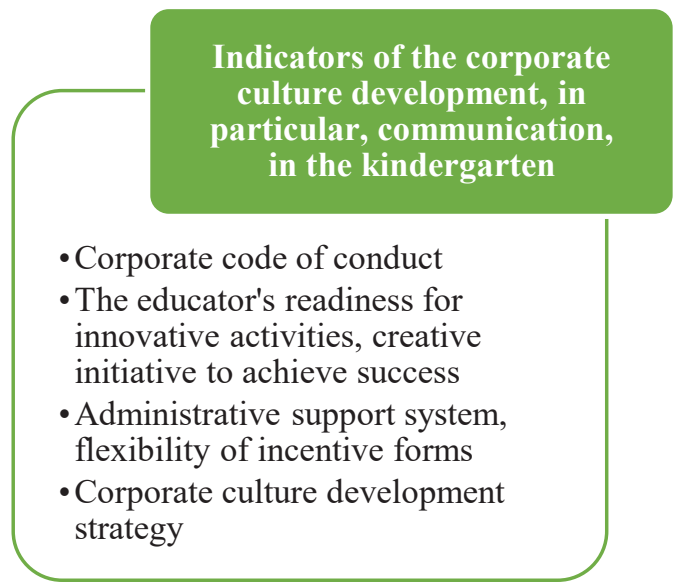

Figure 2. Kindergarten corporate communication system

According to Figure 2, one of the key indicators of the development level of organisational culture is the system of administration support and the presence of stimulation forms, which, in particular, are related to both administration and education subjects. The methods of stimulating the teachers' needs should include (Fig. 3):
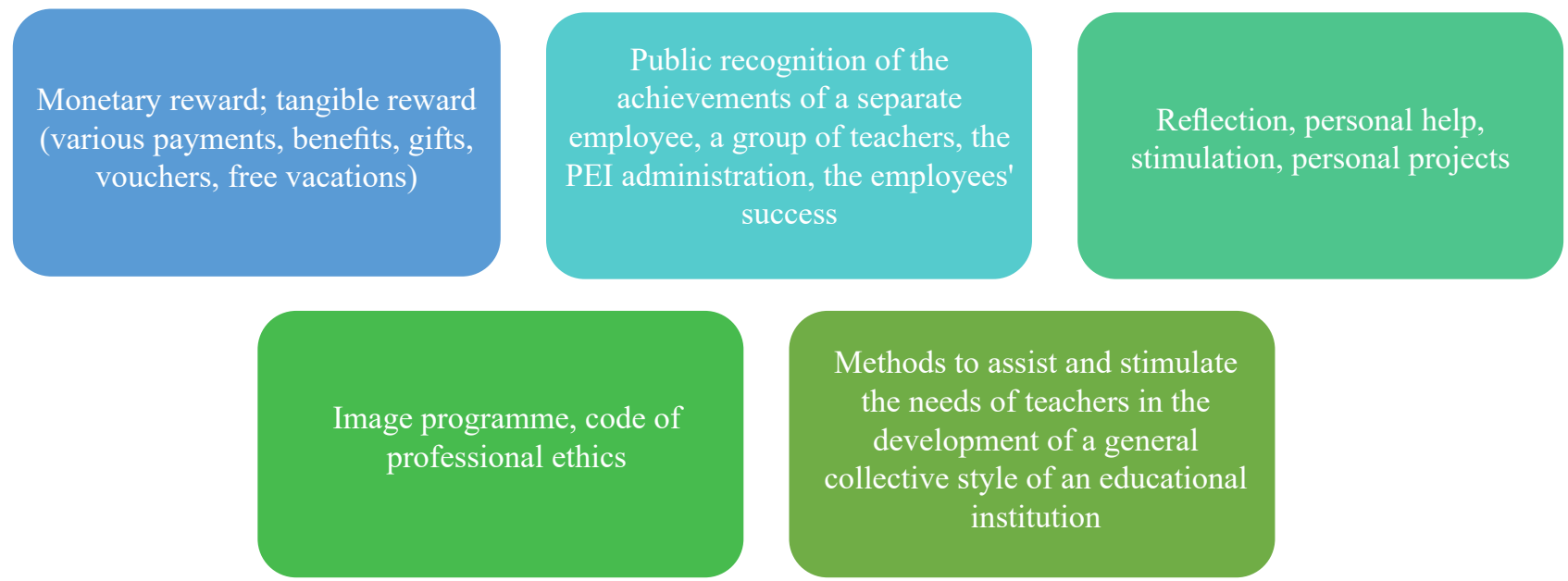

Figure 3. Methods of supporting and stimulating the needs of teachers

E. Gubaydullina stated that gifted teachers are the most functional and creative ones, which is the consequence of following and shaping the customs, considerable standards of the educational and pedagogical environment [12]. Methods of promoting and stimulating the needs of educators are especially necessary if one wishes to express a personal style in professional activity and establish a corporate collective style for a preschool educational institution, which is especially urgent in the conditions of a monetary crisis, finding innovative trends in kindergarten activities, and in the achievement of competitiveness. The basis of style covers all the purposes of the preschool educational organisation, the ideas of its activities, distinctive features from other preschool institutions. Such a view on the corporate style as a part of corporate culture allows determining the main sources of its development, which include (Fig. 4): 


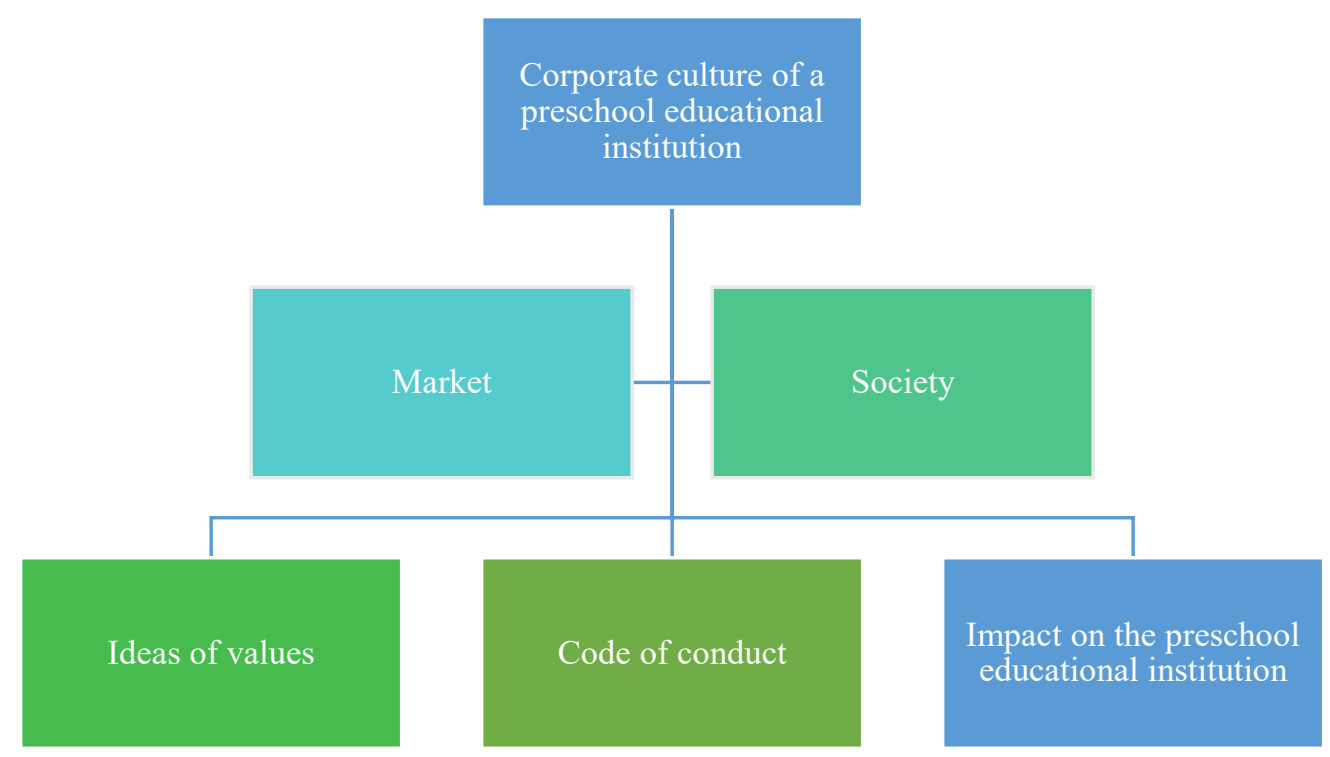

Figure 4. Scheme of corporate culture development of preschool educational institutions

The methodology shown above indicates that the main external causes include: the market (certain economic events) and society (certain political events, national traditions, customs, civilisation, business environment in the field of education, differences of PEI subjects by class and ethnic composition). Internal causes include judgments about the values on which the criteria of workers' behaviour and the activity of the organisation are based (task, strategic development, purposes, administration civilisation, organisational and individual goals). The corporate civilisation of any institution in the education system is considered a well-thought-out strategy for a long period, which allows targeting all employees to complete collective tasks, directing their initiative, and performing productive cooperation at various levels. It ensures the alliance and integrity of the team based on general utility, which helps to maintain what is valuable in the company, in this case, a preschool educational organisation [13]. Therewith, the features of the corporate civilisation development can be determined using the main elements (Fig. 5):

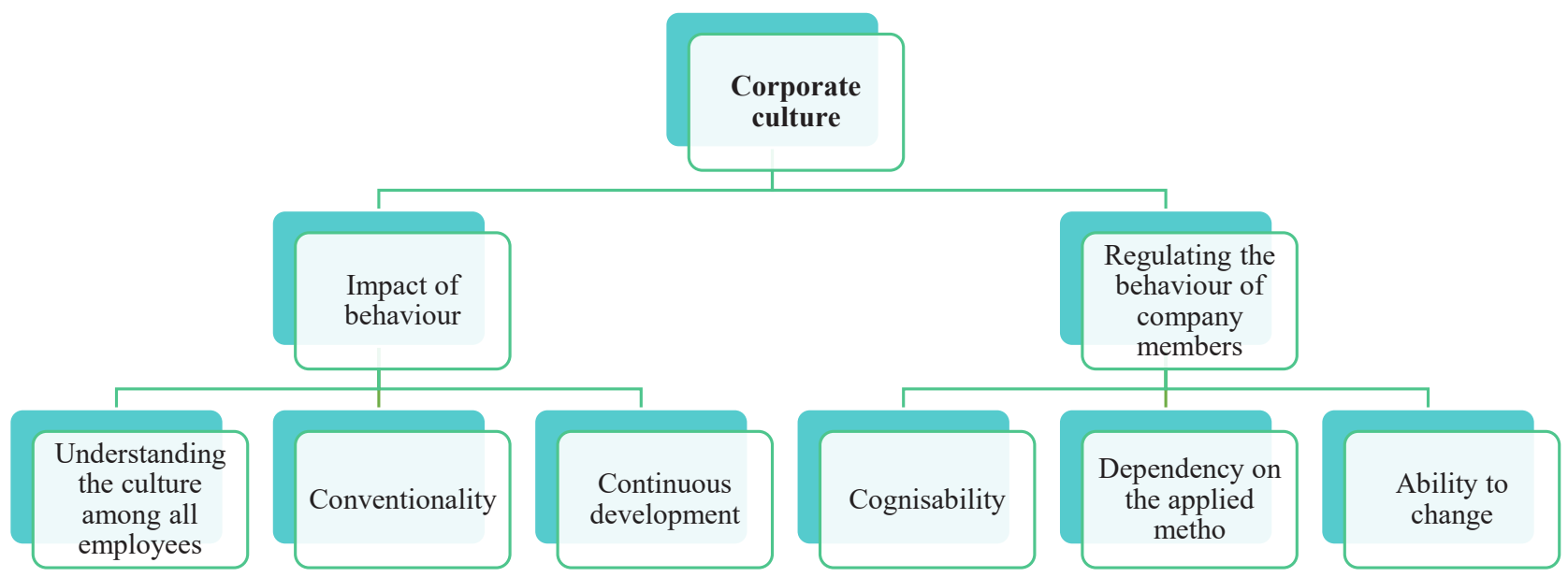

Figure 5. Elements of corporate culture development

From the above, it is possible to draw a conclusion: if the head of a preschool educational institution does not pay direct interest and attention to developing corporate culture, the organisation will not perform well, since only a company with a competent corporate atmosphere will be capable of withstanding today's economic circumstances [14]. In this case, the use of three organisational and pedagogical criteria, namely integrity, cultural conformity, and humanism, is necessary to achieve the highest results in the development of the corporate culture of preschool educational institutions.
The conducted abstract analysis of the administration of a preschool educational institution showed that today the kindergarten is being transferred to the scientific foundations of design, and the development of corporate culture is given less attention than to the issues of structuring and planning. Nevertheless, in the environment of pedagogical education, civilisation is gaining more credence, since a personality-oriented educational environment is impossible without the growth of the culture of the institution, which connects the system of creative methods and universal values 
of pedagogical activity for the development and education of preschoolers.

\section{Specific features of corporate culture development in preschool organisation administration: Asian and European context}

Based on the analysis of scientific literature on the development and functioning of corporate culture in the administration of preschool educational organisations, a theoretical research base was obtained, which contributed to the conduct of empirical research. Thus, the first stage of the experiment was an online survey of administrators of Kazakh and German kindergartens aimed at determining the quality and components of the corporate administration culture. The results of the study are presented in Figure 6 .

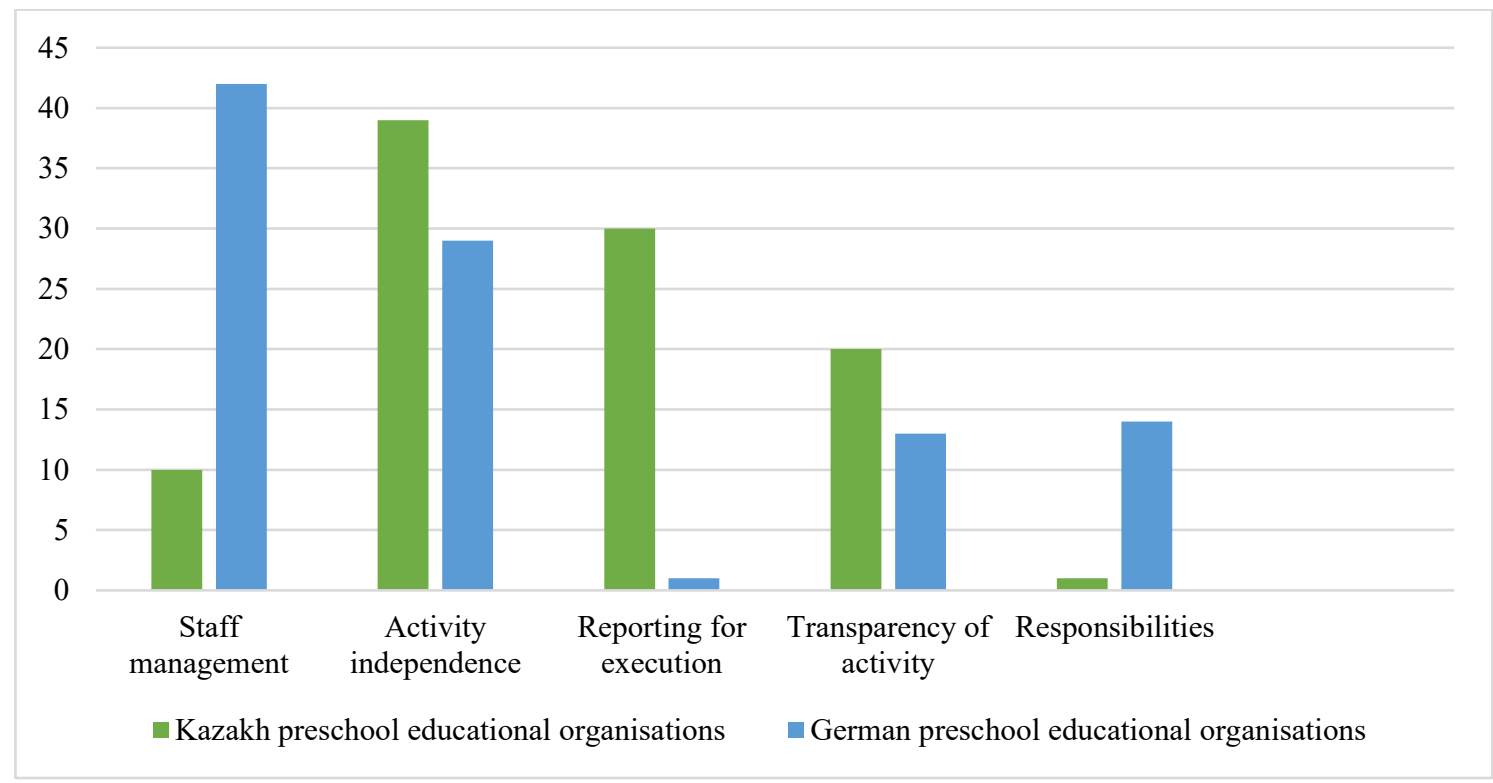

Figure 6. Results of a survey among administrators of preschool educational institutions

According to the survey results, it is worth noting that the administration of Kazakh kindergartens considers independence in the implementation of activities the weakest principle, it was noted by $39 \%$ of respondents as a poorly implemented principle of staff administration in the education system of Kazakhstan, that is, there is a control that interferes with independent decision-making. According to German administrators, the principle of collegiality in administration is the weakest (42\%), and the leading principle is reporting on the results of activities (1\%) in comparison with the Kazakh system of preschool education, where there are a huge number of reporting documents. Then the administrators were asked to list the key competencies of individuals responsible for the corporate culture control and functioning, which are presented hereafter. First, the respondents noted the importance of the strategic activity of the company's and, in particular, from the administrator's part, who should perceive the events from a three-dimensional perspective, anticipate subsequent events based on the analysis of previous ones, develop a strategy in accordance with the activities of a preschool institution, and correlate organisation goals and external circumstances. Similar principles can be traced in foreign research, for example, the one by N. Chen [15] and P. Hallinger [16]. Second, the heads of Kazakh and German kindergartens noted the importance of the administrator's ability in the conditions of corporate culture to manage changes with the lowest probability of negative consequences from external factors, which were considered in research by A. Kusainov [14]. The third competence of the administrator of a preschool educational institution is leadership, which is especially important in the context of the development of corporate culture since a team leader should be able to implement and maintain corporate values, be responsible for educational activities, and preserve a balance in an environment of increased competition. For example, S. Ayuso approved the leadership qualities of the administrator as the primary basis for the successful functioning of the entire organisation [17]. Another component of the corporate culture competence is performance management, which implies the ability to perfectly organise the work of divisions, to assign roles based on the capabilities, knowledge, and skills of subordinates, to set tasks for subordinates, to raise employees' awareness of goals, deadlines, and methods of work. According to R. Nagovitsyn, a proficient leader must possess different administration styles, which, as a result, contributes to understanding employees and establishing appropriate attitudes towards them [18].

In addition, the administrators of kindergartens emphasised the need for leaders to inspire, train their employees, focus on regular improvement of their activities, which is essential in the conditions of a changing culture and the demand to comply with modern standards of education. In this context, it is important for the administrator to be open to dialogue with employees and applicants of preschool education. Then, such competencies as responsibility, 
diligence, focus on the result, activity, initiative, and social intelligence were noted. Responsibility and diligence imply mastery of the highest performing science; truthfulness and decency, the ability to recognise and correct personal mistakes, the desire to do not only the direct responsibilities but also, if necessary, to participate in solving the fundamental tasks of the other divisions. Focus on the result is the probability of setting fundamental, complex purposes and objectives; the willingness to take responsibility for the work outcomes and properties (both successful and not), the ability to measure one's own success by the result, and not by the amount of effort. Activity and initiative include the possession of internal energy and drive, dynamism, and the desire to constantly raise the standards. Social intelligence assumes social resilience and foresight, the ability to perceive reality and predict the behaviour of subordinates. Thus, after conducting a survey among heads of Kazakh and German preschool educational organisations about the key corporate competencies of a preschool institution administrators and the main competencies in the conditions of corporate culture, the listed competencies were compared and presented hereafter (Table 1).

Table 1. Comparative analysis of the corporate competency development among administrators of Kazakh and German kindergartens

\begin{tabular}{|c|c|c|c|}
\hline No. & Corporate competencies & $\begin{array}{c}\text { Kazakh } \\
\text { PEI administrators }\end{array}$ & $\begin{array}{c}\text { German PEI } \\
\text { administrators }\end{array}$ \\
\hline 1 & Strategic importance & $41 \%$ & $50 \%$ \\
\hline 2 & Change management & $63 \%$ & $73 \%$ \\
\hline 3 & Administration & $51 \%$ & $60 \%$ \\
\hline 4 & Performance management & $60 \%$ & $75 \%$ \\
\hline 5 & $\begin{array}{l}\text { Focus on learning and development, } \\
\text { ability to mentor }\end{array}$ & $54 \%$ & $87 \%$ \\
\hline 6 & Responsibility, diligence & $64 \%$ & $75 \%$ \\
\hline 7 & Focus on results and high quality & $63 \%$ & $96 \%$ \\
\hline 8 & Activity, initiative & $50 \%$ & $63 \%$ \\
\hline 9 & Social intelligence & $17 \%$ & $30 \%$ \\
\hline
\end{tabular}

Table 1 shows that $41 \%$ of Kazakh administrators of preschool educational organisations have a high competence level and only $17 \%$ of respondents have a high competence level in the social sphere; $96 \%$ of German PEI administrators have a high competence level, are focused on results and high quality, and $30 \%$ of all German respondents have a high competence level in the field of social intelligence. The lowest percentage among Kazakh and German administrators were obtained by social intelligence competence, i.e., most of the respondents have underdeveloped skills that determine the success of social interaction, including understanding the behaviour of other people, one's own behaviour, the ability to act in accordance with the situation. Thus, the survey results clarify that the readiness of German PEI administrators to implement corporate governance is higher than that of Kazakh ones, the difference is $10-15 \%$. The mission of a preschool educational institution should take into account the range of interests of children, their families, PEI teachers and professionals, the public, suppliers, and partners since this mission reflects the reason for the existence of a kindergarten and consists: in relations with pupils - the implementation of a personality-oriented approach to any preschooler, in the development of certain criteria that are necessary for the child's personality development, the awareness growth, with the obligatory consideration of their individual abilities and potentials; in relationships with family and parents; in relations with society - increasing the competitiveness of the kindergarten by improving the properties of the educational process, expanding the scope of additional services.

Thus, it is impossible to improve the performance of a preschool institution without positive corporate culture, which requires to be developed in a special way along with the proper work of the administrator. Research in the field of preschool administration allows concluding that the interaction between teachers and administrators ensures the congruence of individual and corporate goals.

\section{CONCLUSIONS}

Thus, this study examined the corporate culture in the administration of a preschool educational organisation in two stages. To perform the empirical part of the study, the foreign scientific literature was analysed to determine the specific features inherent to the administration of preschool institutions and the existence of corporate culture within the framework of this organisation. The obtained theoretical base contributed to an online survey among administration representatives of German and Kazakh kindergartens to compare the functioning of organisational culture. The experiment revealed that the weak aspects of the corporate administration culture in Kazakh preschool educational institutions are the actual lack of independence in taking desired measures and high reporting requirements. As for the German kindergartens, the weaknesses of their corporate culture are the low level of staff administration and the lack of complete independence in functioning. In addition, 
a survey was conducted to identify key corporate competencies of administrators of preschool educational institutions, including strategic importance, change management, leadership, performance management, learning orientation, responsibility, focus on results, activity, and social intelligence. Therefore, the distinctive features of Kazakh kindergarten heads are change management, responsibility, and diligence, while German ones are mainly focused on results and learning oriented. Further research will focus on the comparison of corporate culture in the administration of American and European kindergartens.

\section{REFERENCES}

[1] Kisiołek, A., Karyy, O., \& Halkiv, L. (2021). The utilization of Internet marketing communication tools by higher education institutions (on the example of Poland and Ukraine). International Journal of Educational Management, 35(4), 754-767. doi: 10.1108/IJEM-07-2020-0345.

[2] Kisiołek, A., Karyy, O., \& Halkiv, L. (2020). Comparative analysis of the practice of internet use in the marketing activities of higher education institutions in Poland and Ukraine. Comparative Economic Research. Central and Eastern Europe, 23(2), 87-102.

[3] Addai, E. (2020). The effect of organisational culture on teachers' engagement at selected senior high schools in Kumasi Metropolitan. Academia Journal of Educational Research, 8(4), 138-153.

[4] Bersteneva, D.P. (2019). Formation of corporate culture in preschool educational institutions. Retrieved from http://elar.uspu.ru/bitstream/uspu/11141/2/2019bersteneva.pdf.

[5] Naumova, L.A. (2015). Corporate culture as an indicator of development preschool educational institutions. In Situ, 5, 70-75.

[6] Park, J., \& Lee, J. (2016). Measuring the impact of organizational culture on burnout and turnover intention among early childhood teachers. International Information Institute, 19(4), 1077-1082.

[7] Kim, H., \& Hwang, H. (2016). The effects of kindergartens' organizational culture, directors' transformational leadership and teachers' creative personality on kindergarten teachers' teaching flow. Journal of Fisheries and Marine Sciences Education, 28(1), 150-161.

[8] Shamov, T.I., Tyulyu, G.M., \& Litvinenko, E.V. (2017). Assessment of management activities by the head of the preschool educational institution. Moscow: Logos.

[9] Beksary, Zh. (2019). Corporate culture in the organization as a factor improve management efficiency. Wien: Premier Publishing.

[10] Floyd, A. (2016). Supporting academic middle managers in higher education: Do we care? Higher Education Policy, 29(2), 167-183.

[11] Kolesnikov, A.V. (2019). Corporate culture. Moscow: Yurayt.

[12] Gubaydullina, E.V. (2016). Corporate culture of a preschool educational institution. Young Scientist, 9, 538-541.

[13] Atamanchuk, G.V. (2017). General management theory. Moscow: Logos.

[14] Kusainov, A.K. (2013). Quality of education in the world and in Kazakhstan. Almaty: Kursiv.

[15] Chen, N., \& Yang, T.C. (2017). Democracy, rule of law, and corporate governance - a liquidity perspective. Economics of Governance, 18(1), 35-70.

[16] Hallinger, P., \& Chen, Ju. (2015). Review of research on educational leadership and management in Asia. Educational Management Administration \& Leadership, 43(1), 5-27.

[17] Ayuso, S., Rodríguez, M.A., García-Castro, R., \& Ariño, M.A. (2017). An empirical analysis of the stakeholder approach to corporate governance. Business \& Society, 53(3), 414-439.

[18] Nagovitsyn, R.S., Maksimov, Yu.G., Miroshnichenko, A.A., \& Senator, S.Yu. (2017). Implementation of the didactic model of preparing students for innovative practice within the framework of continuing teacher education. Novosibirsk State Pedagogical University Bulletin, 7(5), 7-24. 


\title{
Абрам Бернелл ${ }^{1}$, Віра Позсгай ${ }^{2}$, Ірина Сергіївна Кравець ${ }^{3}$
}

${ }^{1}$ Ханойський університет науки і технологій

1 Дай Ко Вет Роуд, м. Ханой, В'єтнам

${ }^{2}$ Університет у Крагуєваці

34000, бб Йована Цвіїча, м. Крагуєвац, Сербія

${ }^{3}$ Київський національний університет імені Тараса Шевченка

01033, вул. Володимирська, 64, м. Київ, Україна

\section{Корпоративна культура в управлінні дошкільної організації: європейський та азійський контекст}

\begin{abstract}
Анотація. Актуальність дослідження полягає в необхідності впровадження корпоративної культури у сферу дошкільної освіти з метою подальшого розвитку управлінського рівня та педагогічної відповідності працівників, що здійснюють вплив на становлення дошкільників як окремих членів суспільства. Метою роботи є аналіз організаційної культури в управлінні дошкільного закладу, виходячи з порівняння практик азійської та європейської культурних парадигм. Наукова робота складалась з двох етапів, а саме теоретичного та емпіричного, і передбачала застосування загальнонаукових методів дослідження, серед яких аналіз, синтез, порівняння, систематизація, анкетування, опитування, а також статистична обробка даних. Під час дослідження проаналізовано зарубіжну наукову літературу з метою визначення феноменів управління дошкільного закладу та його корпоративної культури. Проведено емпіричне дослідження, суть якого полягала в опитуванні в онлайн-режимі керівників дитячих садків Німеччини та Казахстану. Визначено, що і в німецькій, і в казахській корпоративній культурі управління є слабкі сторони, спільною для яких є відсутність повноцінної свободи в прийнятті рішень і веденні діяльності. 3'ясовано, що двом країнам властивий спільний погляд на формування корпоративних компетенцій керівників, серед яких стратегічна важливість, управління змінами, лідерство, управління виконанням, орієнтація на навчання, відповідальність, зосередженість на результаті, діяльність $\mathrm{i}$ соціальний інтелект. Підтверджено, що німецькі керівники дитячих садів вирізняються результативністю й орієнтацією на навчання, водночас казахські керівники намагаються приділяти увагу відповідальності та ретельності. Практична значимість роботи полягає в наданні порівняння двох поглядів на корпоративну культуру управління в дошкільній організації в контексті європейської і азійської парадигм
\end{abstract}

Ключові слова: дошкільний навчальний заклад, організаційна культура, підготовка педагогів, менеджмент в освіті, анкетування 